\title{
ROLE OF BROWN-ROT FUNGI IN THE BIOREMOVAL OF AZO DYES UNDER DIFFERENT CONDITIONS
}

\author{
Naeem Ali ${ }^{1 *}$, Abdul Hameed ${ }^{1}$, Safia Ahmed ${ }^{1}$ \\ ${ }^{1}$ Department of Microbiology, Quaid-i-Azam University, Islamabad, Pakistan; ${ }^{2}$ Department of Biotechnology, Quaid-i-Azam \\ University, Islamabad, Pakistan.
}

Submitted: December 08, 2009; Approved: April 26, 2010.

\begin{abstract}
The present study is vital to the understanding of bioremediation of structurally different azo dyes by some unusual Brown-rot fungi. Bioremoval of each dye $\left(20 \mathrm{mg} \mathrm{l}^{-1}\right)$ was tested in two different culture media under static and shaking conditions by taking inocula from different fungi. Fungal strains showed varying dyes removal abilities, though considerable high in case of Acid Red (AR) 151(di-azo) as compared to Orange (Or) II (mono-azo). With an exception of Aspergillus tereus SA3, all the fungal isolates showed higher removal of dyes in SDB. Under static condition, the maximum decolorizing fungal strains were; Aspergillus flavus SA2 (67\%) and Alternaria spp. SA4 (57\%) in AR 151, while Penicillium spp. (34 and $33 \%$ ) in Orange II, in SDB and STE, respectively. Bioremoval of dyes was considerably increased when experiments were shifted from static to shaking mode. It was specifically increased (\%) in; AR 151 (255) with Penicillium spp., Or II with A. flavus SA2 (112) and Alternaria spp. (111). The primary mechanism of dyes removal proved to be fungal biosorption. However, reduction of dyes (onto fungal) with formation of their products ( $\alpha$. naphthol, sulphalinic acid and aniline) furthermore revealed that dyes (specifically azo) were actually biodegraded.
\end{abstract}

Key words: Azo dyes, Bio-removal, Bio-decolorization, culture conditions, Fungi

\section{INTRODUCTION}

Among different industrial sectors, Textiles is one of the largest and growing throughout the world. Textile industries consume an extensive and diverse array of chemicals in the form of dyes, dispersants, levelling agents, acids, alkalis, salts and sometimes heavy metals $(7,12)$. A huge amount of water i.e., 95 to $400 \mathrm{l} \mathrm{kg}^{-1}$ fabric (approximately), depending on the ongoing process, is used and most of it latterly discharged as waste from the textile industry. Textile wastewater accounts for about $22 \%$ of the total volume generated from all different types of industries. Generally, wastewater from textile industries has been characterized as; extremely colored and alkaline with high load of Biological Oxygen Demand (BOD), Chemical Oxygen Demand (COD), dissolved and suspended solids $(21,34)$.

Textile dyes are of various types depending upon their; structures and mode of application (30). They have been continuously exhausted $(5-50 \%)$ in the water bodies because of their poor adsorbability to the fibers $(29,53)$. Mostly, dyes are noticeable in water at concentrations, as low as $1 \mathrm{mgl}^{-1}$. Therefore, wastewaters, typically with dyes contents in the range of 10-200 $\mathrm{mg} \mathrm{l}^{-1}$ are extremely colored (54). Presences of dyes raise dissolve solids $(13,51)$, cause rapid diminution of

*Corresponding Author. Mailing address: Department of Microbiology, Quaid-i-Azam University, Islamabad, Pakistan.; Tel: +92-03445000174 +92-5190643194.; E-mail: naeem.ali@gmail.com 
oxygen level in the water bodies (1). Artificial dyes and pigments are made colorfast and stable by using certain additives like; ammonia, chloride, nitrate, phosphate, sulfate, and heavy metals. The recalcitrant nature of dyes in water bodies not only stops biological recycling of nutrients but also reduce the biotic productivity of aquatic ecosystems. In addition, certain dyes and their degradation products have been reported to have toxic to mutagenic affects in almost all forms of life including humans $(6,11,18,47)$.

Dyes, because of their diverse and stable chemical nature, are difficult to remove in wastewater by conventional treatments (31). In this perspective, numerous physical, chemical and biological techniques have been researched in the last few decades. Relatively, biological treatments have been gaining much attention in terms of their low cost and ecofriendly nature. Amongst different bioremediation agents, the roles of bacteria and fungi have always been considered vital for chemical like dyes. Still, the detail metabolic demands of different microbes are complex, impeding their utilization for the remediation of huge amount of colored wastewater. The preliminary biodegradation of dyes (azo) has mostly been supported under anaerobic condition specifically by bacteria; however, further mineralization of dyes' products required aerobic condition. Therefore, sequential anaerobic verses aerobic treatments are convincingly devised for the complete mineralized of dyes at pilot scale. Alternatively, fungal biosorption/bioadsorption $(3,4,52)$ and biodegradation of dyes has always proved efficient under aerobic condition. Among different fungi, White-rot has only been the most researched and an effective tool in the removal of dyes. Enzymes like Lignin peroxidase (LiP), Manganese peroxidase (MnP), Laccase (Lac) of these fungi are meant for the transformation/degradation of lignin present in dead biomass of plants. However, similar enzymes due to their low substrate (lignin) specificities have also been employed quite successfully in the degradation of aromatics like dyes $(14,27$, $35,38,40,45,56)$.

Only a few studies have reported the bioremoval potentials of Brown-rot fungi for different dyes $(5,16,48,57)$. Further research work on such fungal strains is much needed in bioremediation perspective. The present research work addresses the bioremoval potentials of certain Brown-rot fungi for different dyes in batch scale static/shaking conditions. Fungal strains were seeded as inocula in the synthetic colored wastewater in order to check their abilities to grow and utilize different dyes.

\section{MATERIAL AND METHODS}

\section{Chemicals}

All chemical compounds were purchased from Sigma chemicals Co., (St. Louis) and E. Merck (Darmstadt, Germany). They were of the highest purity commercially available and not purified further. The structure of dyes [Acid red (AR) 151 (Di-azo) and Orange (Or) II (Mono-azo)] used in study is showed in Figure 1 (4).

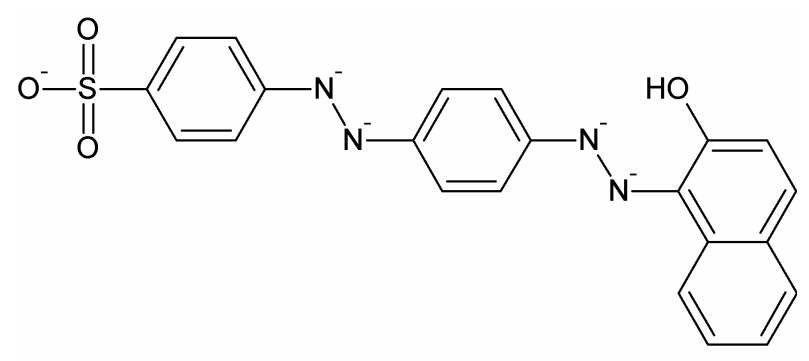

Acid Red 151

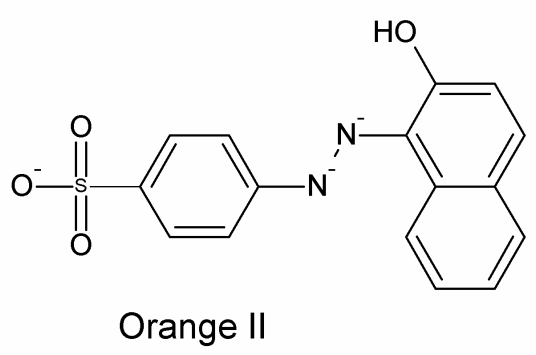

Figure 1. Structure of Acid Red 151 and Orange II

\section{Composition of Saboraud dextrose broth (SDB)}

Saboraud dextrose broth (SDB) was made by adding per liter of distilled water; peptone $10.0 \mathrm{~g}$ and dextrose $40.0 \mathrm{~g}$. $\mathrm{pH}$ of the medium was adjusted to 5.6 using $0.1 \mathrm{M} \mathrm{HCl}$ and $\mathrm{NaOH}$. 


\section{Composition of simulated textile effluent (STE)}

Simulated effluent was made by adding per liter of water (distilled); $\mathrm{CH}_{3} \mathrm{COOH}(99.9 \%) 0.150 \mathrm{ml}$, (NH2) 2 CO $100.0 \mathrm{mg}$, $\mathrm{KH}_{2} \mathrm{PO}_{4} 67.0 \mathrm{mg}, \mathrm{NaHCO}_{3} 840.0 \mathrm{mg}, \mathrm{MgSO}_{4} .7 \mathrm{H}_{2} \mathrm{O} 38.0 \mathrm{mg}$, $\mathrm{CaCl}_{2} 21.0 \mathrm{mg}, \mathrm{FeCl}_{3} \cdot 6 \mathrm{H}_{2} \mathrm{O} 7.0 \mathrm{mg}$ and $\mathrm{C}_{6} \mathrm{H}_{12} \mathrm{O}_{6} 6$ gm. pH of the effluent was adjusted to 8 using $0.1 \mathrm{M} \mathrm{HCl}$ and $\mathrm{NaOH}$.

\section{Isolation and identification of fungi}

Fungal strains were isolated from sludge samples collected from storage pond of textile effluent. These fungi were identified according to Ali et al. (4).

\section{Preparation of fungal inocula}

As describe by Ali et al. (4).

\section{Dyes removal assays}

Removal of each dye (20 mg $\left.\mathrm{m}^{-1}\right)$ was carried out by taking $100 \mathrm{ml}$ of liquid medium (SDB/STE) in $250 \mathrm{ml}$ cotton plugged Erlenmeyer flask. Each dye containing solution was treated with $0.001 \%(\mathrm{w} / \mathrm{v})$ fresh inocula of a specific fungus for 8 days at $30^{\circ} \mathrm{C}$ under static or shaking (100 rotations per minute) conditions. All the experiments were conducted in triplicate to avoid error.

\section{Analytical}

Dyes concentrations: Samples of treated dye containing solutions were drawn at regular intervals ( $24 \mathrm{hrs})$ into plastic vials (size $2.5 \mathrm{ml}$ ) for a period of 8 days. Each sample was initially filtered through Whattman filter paper No 1. Filtrate collected in each sample was centrifuged at 10,000 rpm for 10 minutes, the supernatant filtered through a $0.2 \mu \mathrm{m}$ syringe filter in order to remove residual particulate material. The residual amount of dye in each sample was monitored by taking its absorbance value at $\lambda \max (\mathrm{AR} 151=512,225$, Or $\mathrm{II}=480)$ using a spectrophotometer (Shimadzu UV/VIS). Absorbance values were converted to concentrations by using standard curves (4). Initial and final samples from the experiments with AR 151, Or II and $\mathrm{Db}_{2} \mathrm{RL}$ were also analyzed through High Performance Liquid Chromatography (HPLC) [Agilent 1100 ChemStation, equipped with a diode array detector and LiChrospher 100 RP-18 column (4mm i.d. x 250mm length) containing $5 \mu \mathrm{m}$ packed particles (Merck KgaA, Darmstadt, Germany)]. The solvent system (mobile phase) used for eluting Or II was acetonitrile and $0.03 \mathrm{M}$ ammonium carbonate buffer $(30: 70 \%)$ and for $\mathrm{AR} 151$; it was acetonitrile and $\mathrm{H}_{2} \mathrm{O}(30$ : 70). The flow rate was kept $1.5 \mathrm{ml} \mathrm{min}^{-1}$ during the analysis. Percentage of dye removal in each experiment was calculated by using the formula;

Dye removal $(\%)=$ Initial conc. - final conc. $/$ initial conc. (100)

\section{Statistical}

The crude data obtained in different experiments was statistically analyzed using ANOVA (2 way without replication) and Least significant difference (LSD) tests. Data were expressed as Mean (ave.) \pm Standard error of means (S.E). Results with significant differences $(p=<0.05)$ were alphabetically ranked.

\section{Precaution}

Standard sterilization procedures were followed during experiments.

\section{RESULT}

Fungal strains isolated from textile wastewater pond showed a great deal of variation in the decolorization of azo dyes in two different culture media under static condition $\left(30^{\circ} \mathrm{C}\right.$ for 8 days) (Table 1$)$. Dyes removal (decolorization) appeared to be due to both fungal biosorption and biodegradation. With an exception of A. tereus SA3, all the fungal isolates showed greater removal of dyes in SDB. However, there was observed a no significant difference in results in both the media in case of Or II. Comparatively, $A$. tereus SA3 proved to be least decolorizing in both dyes. Overall, the average removal of AR 151 was significantly higher (18-67 \%) than Or II (22-34\%) by the fungal isolates. It (ave.) (\%) was 54 and 42 in AR 151, 28 and 27 in Or II, in SDB and STE, respectively. Fungal strains which showed better removal (\%) of dyes were including; A. flavus SA2 (67 and 51) and Alternaria spp. SA4 (65 and 57) in AR 151, while Penicillium spp. SA5 in Or II in SDB and STE respectively. 
Table 1. Bioremoval of dyes by different fungi in different culture media under static condition

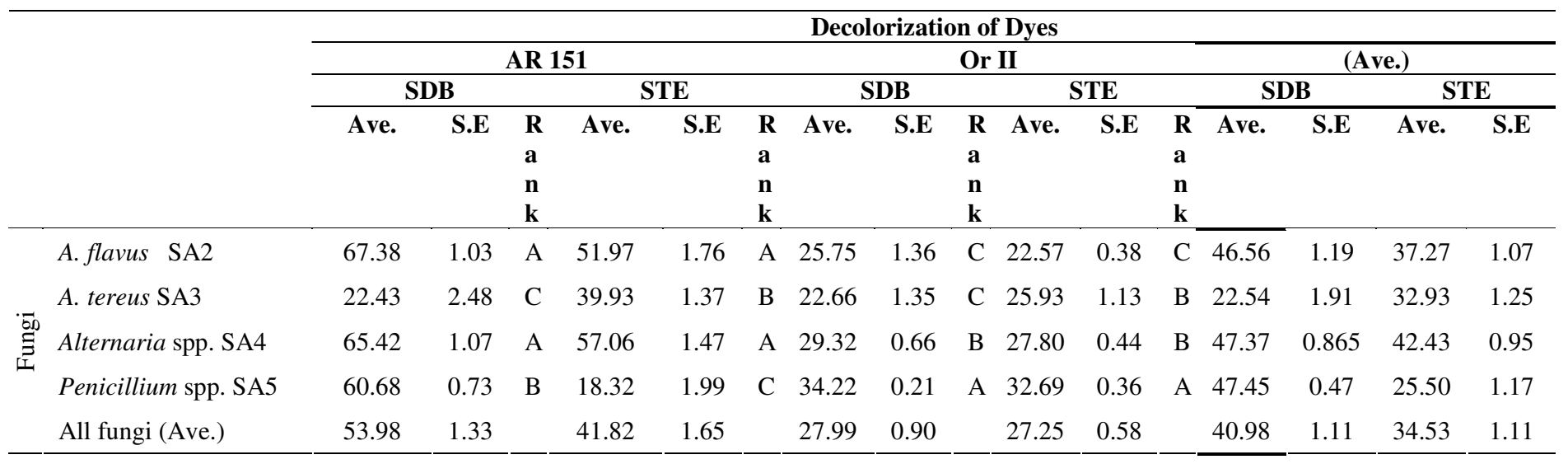

Results of dyes removal (decolorization) by different fungi in shaking cultures are shown in Table 2 and 3. Comparing two dyes, decolorization of AR 151 was maximum (ave. $=76.79 \%$ ) by the entire fungal group. Alternaria spp. SA4 established as the highest decolorizing fungal isolate for both dyes (ave. = 78\%). Contrarily, A. tereus SA3 not only showed least decolorizing ability but it also exhibited less tendency towards degradation of dyes' products. Primarily, the fungal biomasses (pellets) appeared to be responsible in the removal of dye through biosorption/bioadsorption. This observation was later on confirmed through detailed microscopic examination of fungal hypha. Nevertheless, degradation of dyes was positively evident from the production of their products. Dyes that were adsorbed onto fungal biomass turned colorless but this process appeared to be quite slow and it was specifically notice under static condition.

Table 2. Bioremoval/Biodegradation of AR 151 by different fungi under shaking condition

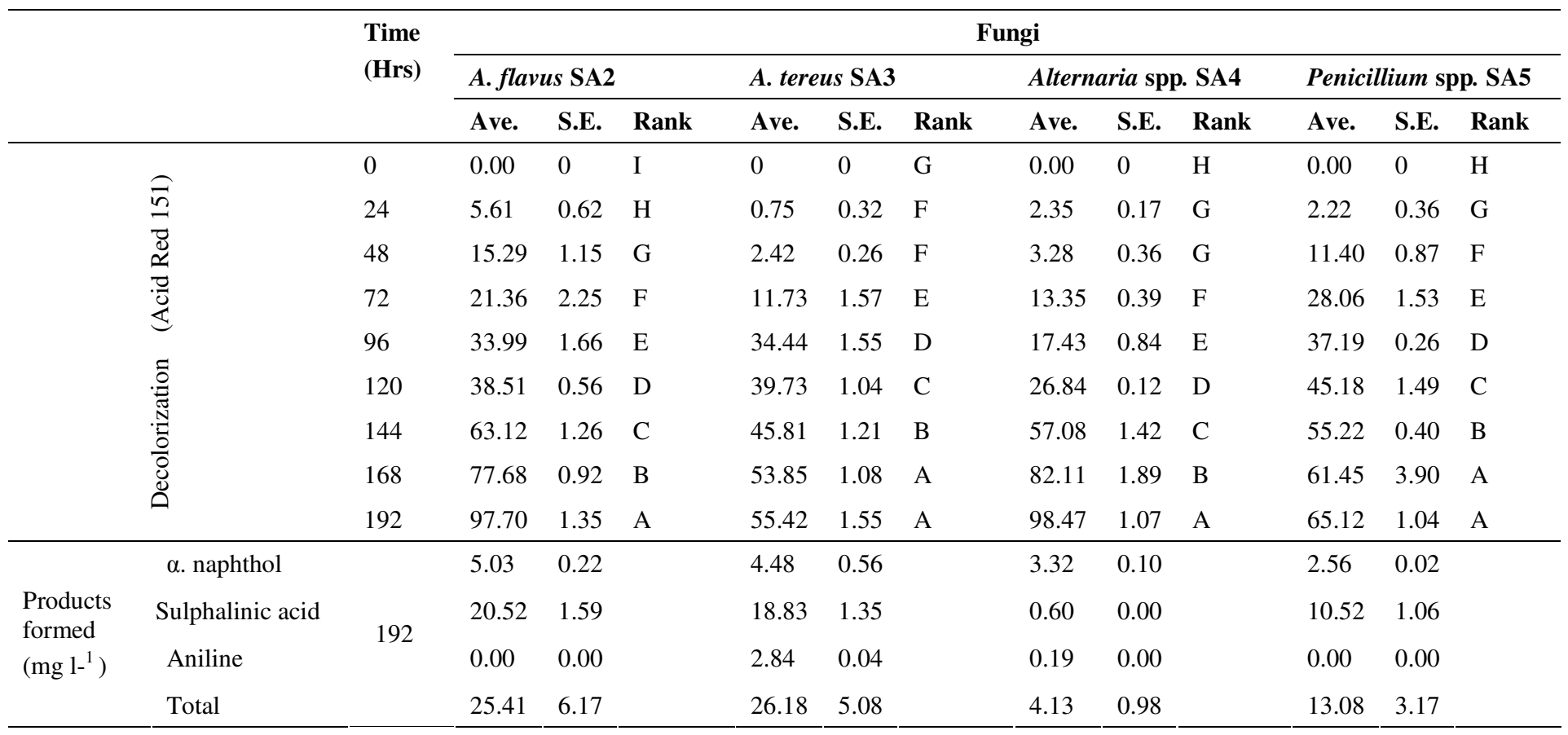


Table 3. Bioremoval/Biodegradation of Or II by different fungi under shaking condition

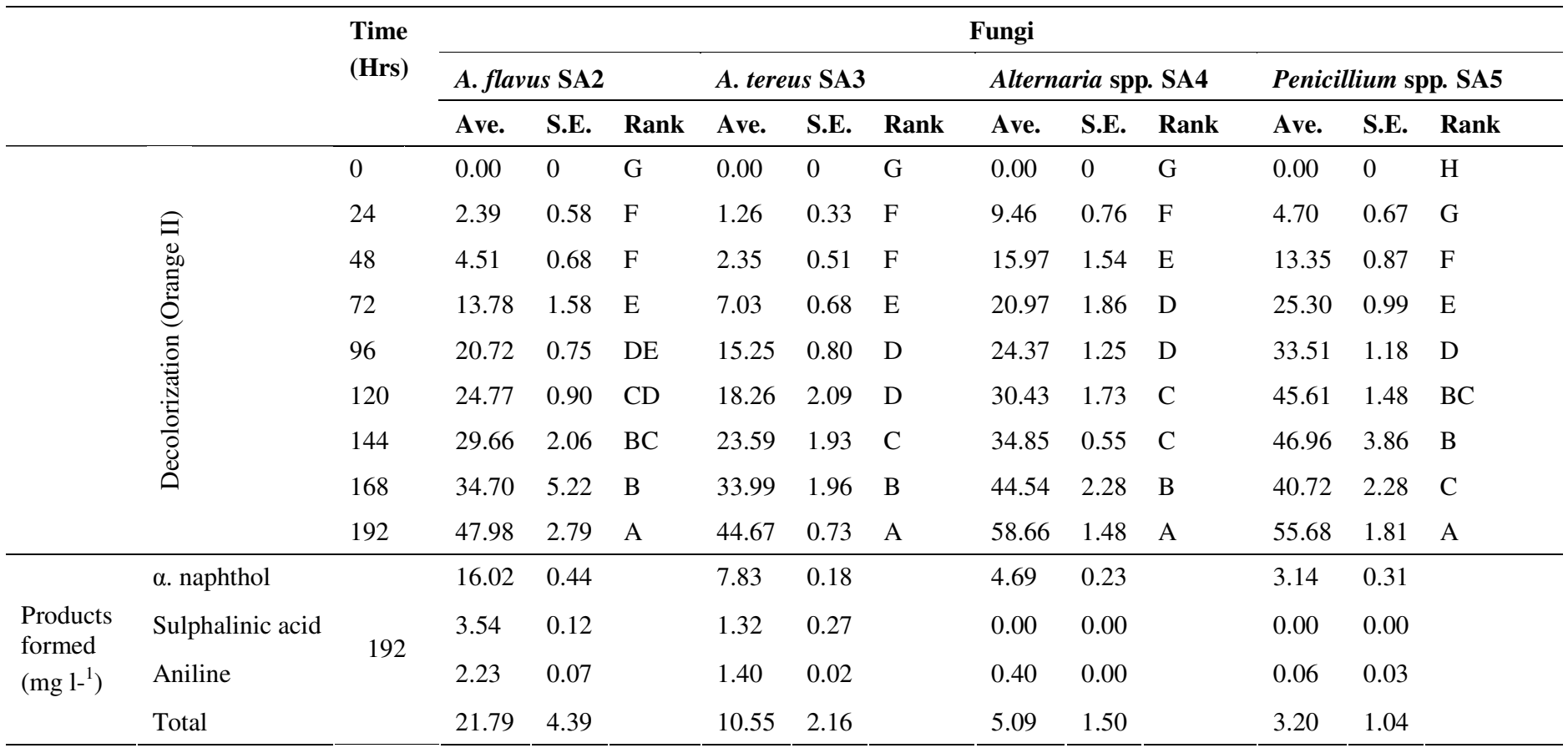

Decolorization of AR 151 (20 $\left.\mathrm{mg} \mathrm{l}^{-1}\right)$ (Table 2) was particularly higher with A. flavus SA2 (97.70\%) and Alternaria spp. SA4 (98.47\%). However, A. tereus SA3 (55\%) and Penicillium spp. SA5 (65), also showed a considerable removal of AR 151 (Table 2). The three main products analyzed in the decolorization of AR 151 included; alpha ( $\alpha$.) naphthol, sulfanilic (S) acid and aniline. The decreasing trend in total products formation with different fungi on $8^{\text {th }}$ day was as follows; SA3>SA2>SA5>SA4. Generally, sulfanilic acid was the most yielded product with all the fungal isolates though its concentrations $\left(\mathrm{mg} \mathrm{l}^{-1}\right)$ were particularly higher with A. flavus SA2 (20.52) and A. tereus SA3 (19). The second most abundant product analyzed was $\alpha$. naphthol, and its concentration remained $\leq 5 \mathrm{mg} \mathrm{l}^{-1}$ in all cases, while aniline was only quantified (2.84) in case of A. tereus SA3. Generally, the rate of decolorization decreased with time and the high time of decolorization was critically noted in the initial $96 \mathrm{hrs}$.

Decolorizations of Or II (20 $\left.\mathrm{mg} \mathrm{l}^{-1}\right)$ (Table 3) were; 48, 44.67, 58.66 and $55.68(\%)$, with 22, 10.5, 5, $3.2\left(\mathrm{mg} \mathrm{l}^{-1}\right)$ of total residual products in case of $A$. flavus SA2, A. tereus SA3, Alternaria spp. SA4 and Penicillium spp. SA5, respectively.
The only major product quantified was $\alpha$. naphthol and its concentration (16 $\mathrm{mg} \mathrm{l}^{-1}$ ) was maximum in case of A. flavus $\mathrm{SA} 2$. The concentrations of the remaining two products kept $\leq$ to $3.5 \mathrm{mg} \mathrm{l}^{-1}$ for all the samples analyzed. Decolorization rate of Or II was specifically high in the initial $24 \mathrm{hrs}$ with Alternaria spp. SA4, It remained high during (hrs); 0-72 in A. flavus SA2, 0-96 in A. tereus SA3, 0-48 in Penicillium spp. SA5.

\section{DISCUSSION}

Studies on Brown-rot fungi involved in the biodegradation of dyes are few $(4,5,22,57)$, nevertheless, the current study has substantially vitalized the role of such fungal isolates. All the five fungal isolates showed removal of both azo dyes, however, it was varying in different culture media and under static/shaking condition (Table 1, 3). Similar dyes removal abilities have mostly been reported in different $\operatorname{WRF}(26,28)$. In this context, small structural differences related to the position and nature of substituents on the aromatic rings of dyes proved to be markedly influencing their biodegradation by 
certain enzymes $(4,14,37,43,54)$. Among dyes, azo are specifically known to be color fast and structurally stable in oxygenic condition (55), due to which they are hard to remove by conventional treatments. This observation is surely justified in case of Or II (mono azo), which proved to be least degraded compared to AR 151 (Di azo) (Table 1). Presence of two azo groups between benzene rings in AR 151 (Figure 1) might have supported in its efficient removal.

Biosorption is reported to be the primary dye removal process in wood rotting basidiomycetes $(7,19,26)$. Similar, mechanism was evident in the present study; however, fungal biomass gradually turned colorless after dyes bioadsorption. Furthermore, analysis of dyes' product (AR 151 and Or II) after 8 days suggested that the dyes were in fact biodegraded. These observations are in line with the findings of Balan and Monterio (7), where they reported the removal of Indigo dye by fungal adsorption and extracellular degradation. Bioadsorption, in particular, has been linked to electrostatic pull; between the negatively charged dyes and the positively charged cell wall components $(2,3)$. The bioremoval abilities for different dyes have been separately related to biosorption and biodegradation in case of $P$. chrysosporium. Fungal biomass showing biosorption of a specific dye remained extremely colored; otherwise, it kept colorless (43). Moreover, biodegradation of metal complex dyes (Grey lanaset G.) revealed dyes degradation in three successive stages. Primary dye adsorption $\left(1^{\text {st }}\right)$ to the fungus lead to the splitting of metal complex bond from it $\left(2^{\text {nd }}\right)$. Finally, the degradation of dyes took place $\left(3^{\text {nd }}\right)$ with the release of products into the culture medium (10).

Dyes degradation properties of the fungi have been reported to change with varying nutrients in different culture media $(15,16,42)$. Therefore, optimization of culture conditions should always be considered as a prerequisite in bioremediation studies. With the exception of A. tereus SA3, all other fungal isolates showed better removal of dyes in SDB than in STE (Table 1). Greater removal of dyes in SDB might be associated with the low $\mathrm{pH}$ and availability of higher glucose (as C source) levels. Glucose not only acts as a reducing agent for dyes (8) but also promotes fungal growth and metabolism $(8,9,41)$. Higher glucose levels also create acidic condition in the culture medium, which thereby supports better removal of dyes (41). Nevertheless, higher levels of glucose can also have a limiting effect on fungal dyes removal abilities (24) as observed in the case of A. tereus SA3.

Cultural stability proved to have an important role in fungal growth and associated dyes' removal and it is noticeable in present study. Decolorization of dyes by the fungal strains was significantly increased when shifted from static to shaking treatment (Table 1, 3). Specifically, maximum increase in decolorization (\%) was observed in; AR 151 (255\%) with Penicillium spp., Or II with A. flavus SA2 (112\%) and Alternaria spp. (111\%). Least improvement in decolorization was noticed in case of; AR 151 (39\%) with A. tereus SA3, Or II (70\%) with Penicillium spp. SA5. Previously, similar results were observe for A. niger SA1 for dyes like Or II, Sb and Db $\mathrm{K}_{2} \mathrm{RL}$. However, no significant change in decolorization was noticed in AR 151 when experiments were shifted from static to shaking condition (4). Likewise, Husseiny (22) also reported the efficient removal of reactive dyes in static culture condition.

Fungi being aerobic organisms normally show better dyes degradation activities under facilitated agitated condition (17, $20,23,28,50,56)$. Shaking increases; the mass (substrate) and oxygen transfer from the culture medium to the cells, thereby, it facilitates optimum fungal growth and enzyme (oxidase) production (50). Nevertheless, no significant change in enzymatic production also reported in different cultural conditions of some fungi (B. adusta R59) (14). Sometimes, the production and stability of peroxidases gets compromised during agitation $(22,25,46,56)$. In a few instances, agitation might not help the production of certain fungal (Irpex lacteus) peroxidases (Mn-Dependent) unless specific nutrients $(0.1 \%$ Tween 80) are incorporated into the medium (49). So, the possibility of fungal degradation of dyes under static condition $(25,43)$ can never be overlooked all together. This idea of using static cultures can be employed for large-scale lagoons used in the treatment of colored effluents (41). 
Decolorization of different dyes takes about 5-30 days $(28,30,33,36)$, moreover, it is often correlated with the production of different ligninolytic enzymes by different fungi $(39,44)$. Results from the present study seem to be certainly falling within this wide range of time (dyes removal was not $100 \%$ within the stipulated time i.e., $192 \mathrm{hrs}$ ) (Table 2, 3). Decolorization rate though varied in different combinations; of dyes and fungi but was generally high in the initial $96 \mathrm{hrs}$. Moreover, it kept on declining with passing time in agitated fungal cultures. Machado et al. (28) also reported this decreasing trend in decolorization with time. This phenomenon might be due to accumulation of dyes products that might have hindered growth and metabolizing potential of the fungi (28, $45,56)$.

Results of present study clearly shows that bioremoval of dyes cannot simply be linked to the White-rot fungi. Other groups of fungi, like Brown-rots can also play a significant role in the bioremediation of recalcitrant aromatics like dyes. Fungal dyes removal capabilities proved to be falling into two main categories; i.e., Biosorption and Biodegradation. Fungal dyes removal is mostly considered through extra-cellular fungal peroxidases. However, further research on understanding the mechanism of dyes reduction (decolorization) after taken up onto the fungal biomass would help in the advancement of bioremediation technologies.

\section{ACKNOWLEDGMENTS}

The authors express genuine thanks to the Department of Microbiology, Faculty of Biological Sciences, Quaid-i-Azam University, Islamabad, Pakistan, for providing research facilities, financial support and many inspiring and illuminating discussions.

\section{REFERENCES}

1. Ademoroti-C, M.A.; Ukponmwan, D.O.; Omode, A..A. (1992). Studies of textile effluent discharges in Nigeria. Environ. Stud. 39(4), 291-296.

2. Aksu, Z.; Tezer, S. (2000). Equilibrium and kinetic modelling of biosorption of Remazol Black B by Rhizopus arrhizus in a batch system: effect of temperature. Process Biochem. 36, 431-439.

3. Aksu, Z.; Calik, A.; Dursun, A.Y.; Demircan, Z. (1999). Biosorption of iron III cyanide complex anions to R. arrhizus: application of adsorption isotherms. Proc. Biochem. 34, 483-491.

4. Ali, N.; Hameed, A.; Ahmed, S. (2008). Decolorization of structurally different textile dyes by Aspergillus niger SA1. W. J. Microbiol. Biotechnol. 24, 1067-1072.

5. Ambrosio, S.T.; Campos-Takaki, G.M. (2004). Decolorization of reactive azo dyes by Cunninghamella elegans UCP 542 under co-metabolic conditions. Bioresource. Technol. 91, 69-75.

6. Bakshi, D.K.; Sharma, P. (2003). Genotoxicity of textile dyes evaluated with Ames test and rec-assay. J. Environ. Pathol. Toxicol. Oncol. 22(2), 101-109.

7. Balan, D.S.L.; Monteiro, R.T.R. (2001). Decolorization of textile indigo dye by ligninolytic fungi Doralice. J. Biotechnol. 89, 141-145.

8. Banat, P.I.M.; Singh D.; Marchant, R. (1996). Microbial process for the decolorization of Textile effluent containing azo, diazo and reactive dyes. Process Biochem. 31, 435-442.

9. Belsare, D.K.; Prasad, D.Y. (1988). Decolorization of effluent from the bagasse based pulp mills by White-rot fungus Schizophyllum commune. Appl. Microbiol. Biotechnol. 28, 301-304.

10. Blanquez, P.; Casas, N.; Font, X.; Gabarrell, X.; Sarra, M.; Caminal, G.; Vicent, T. (2004). Mechanism of textile metal dye biotransformation by Trametes versicolor. Water. Res. 38, 2166-2172.

11. Brown, M.A.; DeVito, S.C. (1993). Predicting azo dye toxicity. Crit. Rev. Environ. Sci. Technol. 23, 249-324.

12. Campos, R.; Kandelbauer, A.; Robra, K.H.; Paulo, A.C.; Gubitz, G.M. (2001). Indigo degradation with purified laccases from Trametes hirsuta and sclerotim rolfsii. J. Biotechnol. 8, 131-139.

13. Chapman, P.M.; Romberg, G.P.; Vigers, G.A. (1982). Design of monitoring studies for priority pollutants. J. Water Pollut. Cont. Fed. 54(3), 292-297.

14. Cho, N.; Bellearz, A.; Ginalska, G.; Kornillowicz, K.; Cho, H.; Ohga, S. (2009). Decolorization and degradation of Daunomycin by Bjerkandera adusta R59 Strain. J. Fac. Agr. Kyushu Univ. 54 (1), 65-71.

15. Daljit, S.A.; Paramjit, K.G. (2000). Laccase production by some Whiterot fungi under different nutritional conditions. Biores. Technol. 73, 283285.

16. Fahraeus, G. (1952). Formation of laccase by Polyporus versicolor in different culture media. Phys. Plant. 5, 284-291.

17. Faison, B.D.; Kirk, T.K. (1985). Factors involved in the regulation of a ligninase activity in Phanerochaete chrysosporium. Appl. Environ. Microbiol. 49, 299-304

18. Forgacs, E.; Cserhati, T.; Oros, G. (2004). Removal of synthetic dyes from wastewaters: a review. Environ. Int. 30, 953-971.

19. Fu, Y.Z.; Viraraghavan, T. (2000). Removal of a dye from aqueous solution by the fungus Aspergillus niger. Wat. Qual. Res. J. Can. 35, 95111.

20. Ge, Y.; Yan, L.; Qing, K. (2004). Effect of environment factors on dye 
decolorization by Penicillium sordida AATCC 90872 in an aerated reactor. Process Biochem. 39, 1401-1405.

21. Ghoreishi, S.M.; Haghighi, R. (2003). Chemical catalytic reaction and biological oxidation for treatment of non-biodegradable textile effluent. Chem. Eng. J. 95, 163-169.

22. Husseiny, S.M. (2008). Biodegradation of the Reactive and Direct Dyes Using Egyptian Isolates. J. Appl. Sci. Res. 4(6), 599-606.

23. Jarosz-Wilkolazka, A.; Kochmanska-rdest, J.; Malarczyk, E.; Wardas, W.; Leonowicz, A. (2002). Fungi and their ability to decolorize azo and anthraquinonic dyes. Enzyme Microb. Technol. 30, 566-572.

24. Kapdan, I.K.; Oztekin, R. (2003). Decolorization of Textile dyestuff Reactive Orange 16 in fed-batch reactor under anaerobic condition. Enzy. Microb. Technol. 33, 231-235.

25. Kirby, N.; Marchant, R.; McMullan, G. (2000). Decolorization of synthetic textile dyes by Phlebia tremellosa. FEMS Microbiol. Lett. 188, 93-96, 20.

26. Knapp, J.S.; Newby, P.S. (1995). Decolorization of dyes by wood rotting basidiomycetes fungi. Water Res. 29, 1807-1809.

27. Machado, K.M.G.; Matheus, D.R.; Bononi, V.L.R. (2005). Ligninolytic enzymes production and Remazol brilliant blue $\mathrm{R}$ decolorization by tropical Brazilian basidiomycetes fungi. Braz. J. Microbiol. 36, 246-252.

28. Machado, K.M.G.; Compart, L.C.A.; Morais, R.O.; Rosa, L.H.; Santos, M.H. (2006). Biodegradation of reactive textile dyes by Basidiomycetous fungi from Brazilian ecosystems. Braz. J. Microbiol. 37, 481-487.

29. McMullan, G.; Meehan, C.; Conneely, A.; Nirby, N.; Robinson, T.; Nigam, P.; Banat, I.M.; Marchant, S.W.F. (2001). A mini review: microbial decolorization and degradation of textile dyes. Appl. Microbiol. Biotechnol. 56, 81-87.

30. Minussi, R.C.; Moraes, S.G.; Pastore, G.M.; Duran, N. (2001). Biodecolorization screening of synthetic dyes by four White-rot fungi in a solid medium: possible role of siderophores. Lett. Appl. Microbiol. $33(1), 21-25$.

31. Mohan, S.V.; Roa, C.N.; Prasad, K.K.; Karthikeyan, J. (2002). Treatment of simulated reactive yellow 22 (Azo) dye effluents using Spirogyra species. Waste Manage. 22, 575-582.

32. Moorthi, P.S.; Selvam, S.P.; Sasikalaveni, A.K.; Murugesan.; Kalaichelvan, P.T. (2007). Decolorization of textile dyes and their effluents using White-rot fungi. Afr. J. Biotechnol. 6 (4), 424-429.

33. Nordström, F.; Terrazas, E.; Welander, U. (2008). Decolorization of a mixture of a textile dyes using Bjerkandera spp. Bol-13. Environ. Tech. 29, 921-929.

34. Nosheen, S.; Nawaz, H.; Khalil-ur-Rehman. (2000). Physico-Chemical characterization of effluents of local textile industries of FaisalabadPakistan. Inter. J. Agr. Biol. 2(3), 232-233.

35. Palmieri, G.; Cennamo, G.; Sannia, G.; (2005). Remazol Brilliant Blue R decolorization by the fungus Pleurotus ostreatus and its oxidative enzymatic system. Enzyme Microb. Technol. 36, 17-24.

36. Pasti-Grigsby, M.B.; Burke, N.S.; Goszczynski, S.; Crawford, D.L. (1996). Transformation of azo dye isomers by Streptomyces chromofuscus A11. App. Environ. Microbiol. 62(5), 1814-1817.

37. Pasti-Grigsby, M.B.; Paszczynski, A.S; Goszczynski, D.L.; Crawford, R.L. (1992). Influence of aromatic substitution patterns on azo dye degradability by Streptomyces spp. and Phanerochaete chrysosporium. Appl. Environ. Microbiol. 58, 3605-3613.

38. Perumal, S.M.; Munuswamy, D.; Sellamuthu, P.S.; Kandasamy, M.; Thangavelu, K.P. (2007). Biosorption of textile dyes and effluents by Pleurotus florida and Trametes hirsuta with evaluation of their laccase activity. Iran. J. Biotech. 5(2), 114-118.

39. Pointing, S.B. (2001). Feasibility of bioremediation by White-rote fungi. Appl. Microbiol. Biotechnol. 57, 20-23.

40. Robinovich, M.L.; Bolobova, A.V.; Vasilchenko, L.G. (2004). Fungal decomposition of natural aromatic structures and xenobiotics. A review. Appl. Biochem. Microbiol. 40, 1-7.

41. Rojek, K.; Roddick, F.A.; Parkinson, A. (2004). Decolorization of natural organic matter by Phanerochaete chrysosporium: the effect of environmental conditions. Water Sci. Technol. Wat. Supply. 4(4), 175182.

42. Sandhu, D.K.; Arora, D.S. (1984). Laccase production by Polyporus versicolor on different substrates. Acta. Biotechnol. 4, 49-57.

43. Sani, R.K.; Azmi, W.; Banerjee, U.C. (1998). Comparison of static and shake culture in the decolorization of textile dyes and dye effluents by Phanerochaete chrysosporium. Folia Microbiol. 43(1), 85-88.

44. Selvam, K.; Swaminathan, K.; Chae, K.S. (2003). Decolorization of azo dyes and a dye industry effluent by a White-rot fungus Thelephora spp. Bioresource Technol. 88, 115-119.

45. Shah, V.; Nerud, F. (2002). Lignin degrading system of White-rot fungi and its exploitation for dye decolorization. A review. Can. J. Microbiol. $48,857-870$.

46. Shin, K.S.; Kim, Y.H.; Lim, J.S. (2005). Purification and characterization of manganese peroxidases of the White-rot fungus Irpex lacteus. J. Microbiol. 43, 503-509.

47. Sponza, D.T. (2002). Necessity of toxicity assessment in Turkish industrial discharges (examples from metal and textile industry effluents). Environ. Monit. Assess. 73(1), 41-66.

48. Sumathi, S.; Manju, B.S. (2000). Uptake of reactive Textile dyes by Aspergillus foetidus. Enzyme Microb. Tech. 27(6), 347-355.

49. Svobodova, K.; Erbanova, P.; Sklenar, J.; Novotny, C. (2006). The role of Mn-Dependent peroxidases in dye decolorization by static and agitated cultures of Irpex lacteus. Folia Microbiol. 51(6), 573-578.

50. Swamy, J.; Ramsay, J.A. (1999). The evaluation of White-rot fungi in the decolorization of textile dyes. Enzyme Microb. Technol. 24, 130-137.

51. Tamburlini, G.; Ehrenstein, O.V.; Bertollini, R. (2003). Children's health and environment: a review of evidence, Environmental Issue Report No. 129, WHO/European Environment Agency, WHO Geneva. pp. 223.

52. Volesky, B. (1990). Biosorption by fungal biomass, pp. 139-171. In: B. Volesky (Ed), Biosorption of Heavy Metals, CRC Press, Boca Raton.

53. Wagner, S. (1993). Improvement in products and processing to diminish environmental impact. COTTECH Conference, Raleigh N.C., 11-12 
November.

54. Willetts J.R.M.; Ashbolt, N.J.; Moosbrugger, R.E.; Aslam, M.R. (2000). The use of a thermophilic anaerobic system for pretreatment of textile dye wastewater. Water Sci. and Technol. 42(5-6), 309-316.

55. Wang, M.; Funabiki, K.; Matsui, M. (2003). Synthesis and properties of bis(hetaryl)azo dyes. Dyes and Pigments. 57, 77-86.

56. Wesenberg, I.; Kyriakides, D.; Agathos, S.N. (2003). White-rot fungi and their enzymes for the treatment of industrial dye effluents. Biotechnol. Adv. 22, 161-187.

57. Zhang, X.; Youxun, L.; Keliang, Y.; Hangjun, W. (2007). Decolorization of Anthraquinone-Type Dye by Bilirubin Oxidase producing nonligninolytic fungus Myrothecium spp. IMER1. J. Biosci. Bioeng. 104(2), 104-110. 